\title{
Yeast opsonisation in children with chronic diarrhoeal states
}

\author{
D C A CANDY, V F LARCHER, J H TRIPP, J T HARRIES, B A M HARVEY, \\ AND J F SOOTHILL
}

Department of Child Health and Department of Immunology, Institute of Child Health, and The Hospital for Sick Children, Great Ormond Street, London

SUMMARY Four patients with defective yeast opsonisation and protracted diarrhoea are reported. Plasma infusions improved the opsonising function in all 4 and the diarrhoea in 3 . This immunological abnormality was assessed in 100 sequential patients with chronic diarrhoea associated with various gastrointestinal disorders: 52 with protracted diarrhoea and failure to thrive of undetermined cause, 26 with 'toddler diarrhoea', 8 with coeliac disease, 5 with chronic inflammatory bowel disease, and 9 with miscellaneous disorders. $23 \%$ of the patients with protracted diarrhoea of undetermined cause had defective opsonisation, a greater proportion $(\mathrm{P}<0.05)$ than that in 'toddler diarrhoea' or the remaining patients, in whom the frequency $(4 \%)$ was similar to that $(5 \%)$ in healthy populations. We suggest that yeast opsonisation be tested in children with protracted diarrhoea, as plasma infusions can be an effective form of treatment.

Some immunodeficiency diseases are associated with diarrhoea, malabsorption, and failure to thrive. Miller et al. ${ }^{1}$ described a syndrome of defective yeast opsonisation, eczema, frequent infections, and death in infants of two families. Soothill and Harvey2 reported that defective yeast opsonisation is common, occurring in about one in 20 of the population, and showed that it is often associated with recurrent infections in young children and with atopy. ${ }^{3}$ Although the precise nature of the defect has not been defined, a defect of the alternative pathway of complement has been suggested. ${ }^{4}$ Plasma corrects the defect in vitro and in vivo and can be of therapeutic value. ${ }^{1-2}$

In this paper we report 4 children with protracted diarrhoea and failure to thrive of undetermined cause, and defective yeast opsonisation. The association of diarrhoea and defective opsonisation

\footnotetext{
Institute of Child Health, London

Department of Child Health

D C A CANDY, Rayne research fellow

J T HARRIES, reader in paediatrics

Department of Immunology

B A M HARVEY, senior chief medical laboratory scientific officer

J F SOOTHILL, professor of immunology

King's College Hospital, London

$\mathrm{V} F$ LARCHER, lecturer in child health

The Hospital for Sick Children, London

J H TRIPP, senior registrar
}

in these patients prompted us to assess the incidence of this immunological abnormality in 100 sequential patients with various gastrointestinal disorders and chronic diarrhoea admitted to the gastroenterology unit.

\section{Materials and methods}

The children had all been referred to The Hospital for Sick Children for further investigation of chronic diarrhoea, with or without failure to thrive.

Yeast opsonisation was measured using the method of Soothill and Harvey. ${ }^{2}$ The diagnostic value $(<2.5$ yeast/polymorph) described by them, and subsequently confirmed in a larger population of healthy children, ${ }^{15}$ was used. Inulin activation of complement was determined using the method of Soothill and Harvey. ${ }^{4}$ Jejunal biopsies were obtained by standard techniques; half the specimen was immediately snap frozen and stored at $-70^{\circ} \mathrm{C}$ until analysis. Mucosal $\left(\mathrm{Na}^{+}-\mathrm{K}^{+}\right)$-ATPase and adenylate cyclase activities were measured as previously reported. ${ }^{5}$ Statistical analysis was by the $\chi^{2}$ test with continuity correction.

\section{Case histories}

Table 1 summarises the results of the relevant gastrointestinal and immunological investigations performed on the 4 patients. Unless otherwise 
Table 1 Relevant gastrointestinal and immunological investigations in index patients

\begin{tabular}{|c|c|c|c|c|c|c|c|c|c|}
\hline \multirow[t]{2}{*}{ Case } & \multirow[t]{2}{*}{ Sex } & \multicolumn{4}{|c|}{ Jejunal biopsy } & \multirow{2}{*}{$\begin{array}{l}\text { Opsonisation index } \\
\text {-(yeast/polymorph) }\end{array}$} & \multirow{2}{*}{$\begin{array}{l}\text { Insulin activation of } \\
\text { alternative pathway } \\
\text { (change in titre) } \neq\end{array}$} & \multicolumn{2}{|c|}{ Duodenal intubation } \\
\hline & & Histology & $\begin{array}{l}\text { Disaccha- } \\
\text { ridases }\end{array}$ & $\begin{array}{l}\text { Adenylate } \\
\text { cyclase } \\
\text { (pmol/mg } \\
\text { per min)* }\end{array}$ & $\begin{array}{l}\left(\mathrm{Na}^{+}-\mathrm{K}^{+}\right) \\
-A T P a s e \\
(\mu \mathrm{mol} / \mathrm{mg} \\
\text { per } h) \dagger\end{array}$ & & & Culture & $\begin{array}{l}\text { Pancreatic } \\
\text { enzyme } \\
\text { activity }\end{array}$ \\
\hline $\begin{array}{l}1 \\
2 \\
3 \\
4\end{array}$ & $\begin{array}{l}\mathbf{F} \\
\mathbf{F} \\
\mathbf{F} \\
\mathbf{M}\end{array}$ & $\begin{array}{l}\text { PVA } \\
\text { PVA } \\
\text { Normal } \\
-\end{array}$ & $\begin{array}{l}\text { Normal } \\
\text { Normal } \\
\text { Normal } \\
-\end{array}$ & $\begin{array}{l}9 \cdot 3 \\
13 \\
-\end{array}$ & $\begin{array}{l}1 \cdot 77 \\
1 \cdot 87 \\
-\end{array}$ & $\begin{array}{l}1 \cdot 26 \\
0 \cdot 90 \\
0 \cdot 81 \\
0.90\end{array}$ & $\begin{array}{l}1 \\
2 \\
2 \\
1\end{array}$ & $\begin{array}{l}\text { Normal } \\
\text { Normal } \\
- \\
-\end{array}$ & $\begin{array}{l}\text { Normal } \\
\text { Normal } \\
- \\
-\end{array}$ \\
\hline
\end{tabular}

*Control range, $7 \cdot 3-18.8 \mathrm{pmol} / \mathrm{mg}$ protein per minute (basal activity).

tControl range, $1 \cdot 39-4 \cdot 59 \mu \mathrm{mol} / \mathrm{mg}$ protein per hour.

$\ddagger$ Normal change in titre $>3$.

PVA = partial villous atrophy; - not done.

indicated results of chest $x$-ray, barium studies, faecal microscopical examination and culture, and tests for reducing substances and chromatography, and plasma electrolytes, urea, calcium, phosphate, alkaline phosphatase, total proteins, albumin, aspartate transaminase, and alanine transaminase were normal. Also normal were immunoglobulin concentrations (except Case 1), neutrophil and lymphocyte counts, T- and B-cell populations, haemolytic complement, and C3. Apart from the defective yeast opsonisation (Table 1), complement activation by inulin was defective in all of them and by Escherichia coli endotoxin in three.

Unless otherwise stated, all had been born at term by spontaneous delivery to healthy unrelated parents, and were of appropriate birthweights with no relevant family history.

Case 1. The mother had often had skin infections as a child; the father and siblings were well. Two maternal uncles had died in childhood: one aged 3 months with eczema, recurrent chest infections, and diarrhoea, and the other at 6 years with recurrent chest infections. Our patient was breast fed for 5 months, during which time she had been well and thrived. She then developed paronychia, recurrent impetigo, mouth ulcers, and increasingly frequent chest infections; at 4 years she developed chickenpox with severe secondary infection, followed by an episode of watery diarrhoea which had resolved spontaneously. At 5 years she developed profuse watery diarrhoea with impetigo and mouth ulcers which had persisted for 8 weeks before her referral.

She was a pale, sick girl (weight and height $<3$ rd centile), with fever, finger clubbing, impetigo, mouth ulcers, and hepatosplenomegaly. The respiratory rate was raised, crepitations were present over both lung fields, and chest $x$-ray showed the appearances of widespread bronchiectasis; she produced about $20 \mathrm{ml}$ purulent sputum daily, which grew Haemophilus influenzae and Pseudomonas aeruginosa.
Serum iron, folate, potassium, gastrin, and IgA concentrations were low, and salivary IgA was not detected; jejunal biopsy showed the appearances of partial villous atrophy. The profuse diarrhoea (1-1.5 litres of stool/24 h) isotonic with plasmathat is $1 / 20$ of her body weight-necessitated intravenous feeding. The administration of fresh frozen plasma $(20 \mathrm{ml} / \mathrm{kg}$ every 5 days) resulted in a great reduction in stool volume, the sputum volume and mouth ulcers improved, and the yeast opsonisation rose (Figure). During the subsequent 6 months she gained $1 \mathrm{~kg}$ in weight (3rd centile), but the appearances of a repeat small intestinal biopsy were unchanged.

Case 2. The maternal grandfather has bowel cancer but otherwise there was no family history of gastrointestinal disease or immunodeficiency. Our patient was breast fed for 6 months and had remained well, but after the simultaneous introduction of cows' milk and solid foods, she developed frequent loose, pale stools and failure to thrive. On referral, at age one

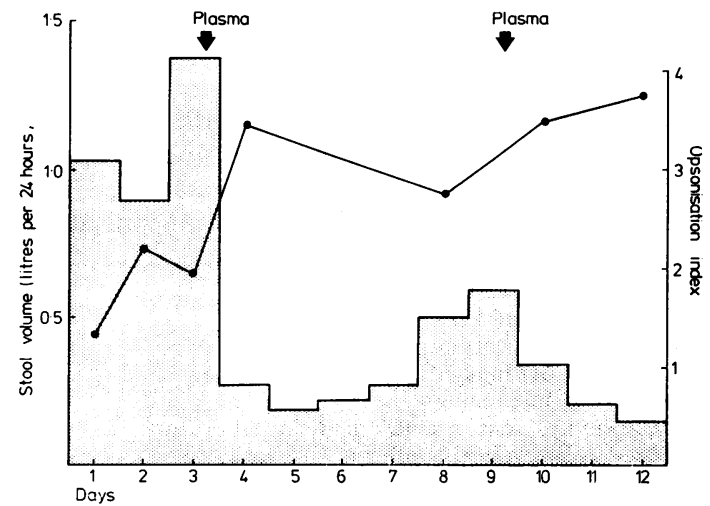

Figure Response of stool volume (histogram) and opsonisation index to plasma infusions in Case 1 ( opsonisation index). 
year, her weight was $1 \mathrm{~kg}$ below the 3 rd centile and her height on the 25 th centile. Serum iron and folate levels were reduced, faecal fat output was slightly increased $(6 \cdot 3 \mathrm{~g} / 24 \mathrm{~h} ; 22 \cdot 2 \mathrm{mmol} / 24 \mathrm{~h})$, and serum IgE antibodies to bovine serum albumin and $\beta$-lactoglobulin were undetectable. After four infusions of pooled fresh frozen plasma $(20 \mathrm{ml} / \mathrm{kg})$ given at weekly intervals the yeast opsonisation returned to normal $(4 \cdot 06)$ but this was not accompanied by any clinical improvement. A gluten- and cows' milk protein-free diet was instituted together with supplementary vitamins, iron, and folate. On this regimen her stools became normal and she thrived, despite the opsonisation index returning to its previously low level (1.94). Small intestinal biopsy was normal 4 months later, and remained so 3 months after the reintroduction of cows' milk and after a similar period on a gluten-containing diet. She remains asymptomatic and continues to thrive on a normal diet.

Case 3. She was born at term by breech delivery, weighing $1.42 \mathrm{~kg}$. The mother and a sister have asthma but there was no family history of gastrointestinal disease or immunodeficiency. Our patient was bottle fed and at age 2 months, shortly after the introduction of solid foods, she had developed intermittently loose stools (up to nine a day for 2 to 4 days each week), which did not improve after dietary withdrawal of milk. On referral at 5 years her height was on the 3 rd centile and her weight was $1 \mathrm{~kg}$ below the 3rd centile; she was irritable and the abdomen was distended. Concentrations of serum phosphate and potassium were low, and IgE antibodies to bovine serum albumin and $\beta$-lactoglobulin were not detected. She received pooled fresh frozen plasma $(20 \mathrm{ml} / \mathrm{kg})$ weekly for 9 weeks. The opsonisation index rose after the first and fourth infusions, but did not change after the second and third. During this time her mood improved, and after the fourth infusion the diarrhoea resolved and she began to thrive. Four days after the last plasma infusion diarrhoea recurred, the opsonisation index having fallen to $0 \cdot 10$. Her symptoms were not sufficiently severe to justify further plasma infusions and her weight has increased to the 3rd centile.

Case 4. He was born post-term weighing $3.49 \mathrm{~kg}$. The mother reacts to bee stings with extensive local swelling; she has four children from a previous marriage, three of whom have repeated upper respiratory tract infections, while the other has repeated skin pustules. There was no other relevant family history. Breast feeding was supplemented with bottle feeding and during the first week our patient passed up to 20 watery stools a day, and developed hypoproteinaemic $(23 \mathrm{~g} / \mathrm{l})$ oedema. At 7 weeks he was wasted (weight $0.95 \mathrm{~kg}$ below $3 \mathrm{rd}$ centile) and dehydrated. $\mathrm{Hb}$ was $8.9 \mathrm{~g} / \mathrm{dl}$, and $x$-rays showed patchy consolidation of the left lung base and mastoiditis with bone destruction. He was treated with intravenous feeding and had recurrent episodes of hypoglycaemia, cellulitis, and left otitis media. Subsequently a diet containing comminuted chicken, medium chain triglycerides, and glucose was introduced and at 3 months he began to thrive; a normal diet was gradually introduced from 4 months. A left cortical mastoidectomy was performed at 5 months, a radical mastoidectomy at 7 months; at 10 months he was discharged from hospital with a persistently discharging left ear and diarrhoea. The opsonisation index was first determined at 2 years, after which plasma infusions $(20 \mathrm{ml} / \mathrm{kg})$ were administered every 3 weeks. The opsonisation index became normal, with improvement in the ear discharge and diarrhoea. Since then monthly attacks of loose stools (up to eight stools a day lasting for about a week) have recurred, but despite this his height and weight have increased and are on the 90th and 50th centiles respectively.

\section{Family studies}

Yeast opsonisation was defective in the mothers of Cases 1 and 4, and in the siblings of Cases 3 and 4 (Table 2). The opsonisation index of the mother of Case 2 was just above the arbitrary diagnostic limit.

Yeast opsonisation in children with chronic diarrhoea The association of defective opsonisation, chronic diarrhoea, and failure to thrive, and the impressive response to plasma infusions in Cases 1,3 , and 4, prompted us to measure yeast opsonisation in 100 children with chronic diarrhoea due to a variety of causes who had been admitted to the gastroenterology unit. The diagnostic categories are shown in Table 3. 52 of them had protracted diarrhoea and failure to thrive; extensive investigations failed to show a definitive cause and they presented features similar to those previously reported. ${ }^{6} 26$ had 'toddler diarrhoea' (that is chronic intermittent diarrhoea of undetermined

Table 2 Yeast opsonisation* in families of index patients

\begin{tabular}{llll}
\hline Case & Mother & Father & Siblings \\
\hline 1 & $2 \cdot 28$ & $4 \cdot 22$ & $4 \cdot 86$ \\
2 & $2 \cdot 56$ & $5 \cdot 10$ & None \\
3 & $3 \cdot 40$ & $3 \cdot 86$ & $0 \cdot 88,3 \cdot 00$ \\
4 & $2 \cdot 28$ & $3 \cdot 20$ & $2 \cdot 38,4 \cdot 68$ \\
\hline
\end{tabular}

*Normal yeast opsonisation $>2 \cdot 5$. 
Table 3 Defective yeast opsonisation in 100 children with chronic diarrhoea

\begin{tabular}{lrrr}
\hline Category & No. & No. defective & \% defective \\
\hline $\begin{array}{l}\text { Chronic diarrhoea } \\
\quad \text { With failure to thrive }\end{array}$ & 52 & 12 & 23 \\
$\begin{array}{l}\text { Without failure to thrive, } \\
\quad \text { toddler diarrhoea' }\end{array}$ & 26 & 1 & 4 \\
$\begin{array}{l}\text { Coeliac disease } \\
\text { Chronic inflammatory }\end{array}$ & 8 & 0 & 0 \\
$\quad$ bowel disease & 5 & 1 & 20 \\
Miscellaneous & 9 & 0 & 0 \\
Total & 100 & 14 & 14 \\
\hline
\end{tabular}

cause with growth and weight gain parallel to population centile charts), 8 had coeliac disease, and 5 had chronic inflammatory bowel disease (ulcerative colitis (3), Crohn's disease (2) ). Of the miscellaneous patients, 4 had short bowels after surgical resection, 3 had Shwachman's syndrome, one had cystic fibrosis, and one had tropical sprue.

$12(23 \%)$ of the 52 patients with protracted diarrhoea and failure to thrive had defective opsonisation, but the defect was present in only one of the children with 'toddler diarrhoea', one with Crohn's disease, none of the patients with coeliac disease, and none in the miscellaneous group.

The frequency of the defect was greater $(P<0.05)$ in the first group compared with the 'toddler diarrhoea' group or the remaining patients, in whom the frequency $(4 \%)$ was similar to the $5 \%$ reported in healthy populations. ${ }^{2}$

\section{Discussion}

One in 20 of the general population cannot opsonise baker's yeast for polymorph phagocytosis. ${ }^{27}$ The precise nature of the defect or defects has not yet been defined, but there is some evidence that the alternative pathway of complement is involved. ${ }^{4}$ Although diarrhoea has been reported in some patients with defective opsonisation, ${ }^{1-2} 11$ there had been no systematic study in different diarrhoeal states.

Our 4 patients had unexplained chronic diarrhoea with failure to thrive. In Case 1 the diarrhoea was cholera-like in volume, consistency, and composition, and the response to plasma infusions was striking.

The association of defective opsonisation, salivary and serum IgA in Case 1 is of interest. Although isolated IgA deficiency has been reported in associawith chronic diarrhoea, ${ }^{8-9}$ the striking response to plasma infusions, which is unlikely in isolated IgA deficiency, suggests that the opsonising defect was the more important of the two abnormalities. Nevertheless it seems likely that the IgA deficiency is playing a part since this patient (Case 1) is by far the most severely affected of the 4 , and the only one requiring continued plasma infusions. In this patient it was possible to increase the intervals between infusions to 3 weeks with only slight recurrence of symptoms and with little reduction in opsonisation index. In contrast the opsonisation index had fallen to low values after only one week in the other 3 patients treated with plasma. The reason for this difference is not clear but there have been no reactions to suggest an antibody response to a component in the plasma, which the recipient lacks. Although most infusions were associated with a rise in opsonisation index this did not occur after all infusions in Case 3; a possible explanation was that the donor plasma was defective in view of the incidence of the abnormality in the general population.

Defective yeast opsonisation may be secondary to severe liver disease,$^{16}$ or to complement consumption in vivo, ${ }^{10}$ but there was no evidence for this in any of our 4 patients. Complement fixation by inulin was defective in all of them while haemolytic complement and $C 3$ levels were normal, suggesting a defect in the alternative pathway of complement. This is in contrast to the 10 patients with protracted diarrhoea studied by Guiraldes $e t$ al., ${ }^{11}$ who found that half of them had low levels of total haemolytic complement in association with defective opsonisation.

The family studies are probably consistent with a dominant mode of inheritance for the defect with symptoms only in the offspring of affected mothers, as previously suggested ${ }^{2}$ opsonisation values were borderline in 2 mothers and normal in one other. However, IgG or IgM antibodies to yeast could, in theory, produce false-positives in defective sera.

In order to assess the frequency of defective opsonisation in various chronic diarrhoeal states of childhood, we measured yeast opsonisation in 100 patients with chronic diarrhoea. Compared with control populations a strikingly increased frequency $(23 \%)$ of defective opsonisation was found in patients with protracted diarrhoea of undetermined cause and failure to thrive. The normal values found in some of the other groups with severe diarrhoea indicate that it is by no means an invariable effect of diarrhoea or failure to thrive.

As in other immunodeficiency states the precise pathogenesis of the diarrhoea has not been defined. No pathogenic bacteria or Giardia sp. were recovered from duodenal juice or stools. In Case 2 transient cows' milk protein or gluten intolerance, or both, remains a possible explanation for the diarrhoea, and in this context it is of interest that the incidence of defective opsonisation is increased in atopic individuals compared with control populations. ${ }^{3}$

There is now evidence that the intestinal mucosal enzymes, adenylate cyclase, and $\left(\mathrm{Na}^{+}-\mathrm{K}^{+}\right)$ 
-ATPase are fundamental to the regulation of fluid and solute movements across the intestine. ${ }^{12-13}$

Adenylate cyclase mediates the secretion of water and electrolytes in diarrhoea induced by certain bacterial toxins such as the heat-labile enterotoxins of E. coli and Vibrio cholerae. ${ }^{12}$ The diarrhoea of Case 1 was of cholera-like volume and consistency, but the normal specific activity of adenylate cyclase in small intestinal biopsies of this patient, and Case 2, makes such a mechanism for the diarrhoea unlikely. Diarrhoea in virus-infected animals is associated with impaired absorption, and reduced activity of $\left(\mathrm{Na}^{+}-\mathrm{K}^{+}\right)$-ATPase in intestinal mucosa. ${ }^{14}$ The activity of this enzyme was also normal in Cases 1 and 2, so that the two established mechanisms for watery diarrhoea, infective and other, are apparently excluded.

Protracted diarrhoeal states in children, particularly in early infancy, often pose major problems in diagnosis and management. Studies concerned with the pathophysiological mechanisms operating in the genesis of the diarrhoea in these patients represent important and challenging areas for research. The recognition of the common association between defective yeast opsonisation and protracted diarrhoea of undetermined cause in young children, whether associated with skin lesions or respiratory tract infections, is important as plasma infusions can be an effective form of treatment. We suggest that determination of the yeast opsonisation index should be an integral part of the investigation of such children. The finding of defective opsonisation in a symptomatic patient however, should not preclude the search for other causes, since the association may be a chance one in any individual because of the frequency of the defect in the community.

D C A C acknowledges the financial support of the Rayne Foundation.

\footnotetext{
References

1 Miller M E, Seals J, Kaye R, Levitsky L C. A familial plasma associated defect of phagocytosis: a new cause of recurrent bacterial infections. Lancet 1968; 2 : 60-3.
}

2 Soothill J F, Harvey B A M. Defective opsonisation. A common immunity deficiency. Arch Dis Child 1976; 51: 91-9.

3 Turner M W, Mowbray J F, Harvey B A M, Brostoff J, Wells R S, Soothill J F. Defective yeast opsonisation and C2 deficiency in atopic patients. Clin Exp Immunol 1978; 34: 253-9.

4 Soothill J F, Harvey B A M. A defect of the alternative pathway of complement. Clin Exp Immunol 1977; 27: 30-3.

5 Tripp J H, Manning J A, Muller D P R, et al. Mucosal adenylate cyclase and sodium-potassium stimulated adenosine triphosphatase in jejunal biopsies of adults and children with coeliac disease. In: McNicholl B, McCarthy C F, Fottrell P F, eds. Perspectives in coeliac disease. Lancaster: MTP Press, 1978: 461-70.

6 Larcher V F, Shepherd R, Francis D E M, Harries J T. Protracted diarrhoea in infancy. Analysis of 82 cases with particular reference to diagnosis and management. Arch Dis Child 1977; 52: 597-605.

7 Yamamura M, Valdimarsson H. A new semi-quantitative radiometric opsonin assay. Selective measurement of opsonizing capacity of the alternative pathway. Immunology 1978; 34: 689-94.

8 Crabbé P A, Heremans J F. Lack of gamma A-immunoglobulin in the serum of patients with steatorrhoea. Gut 1966; 7: 119-27.

- Savilahti E, Pelkonen P, Visakorpi J K. IgA deficiency in children. A clinical study with special reference to intestinal findings. Arch Dis Child 1971; 46: 665-70.

10 Editorial: Complement activation and disease. $\mathrm{Br} \mathrm{Med} J$ 1976; i: 416-7.

11 Guiraldes E, Sörensen R, Rebolledo L, Carmona A, Gutiérrez C. Factores immunológicos en la diarrea infanta. Rev Chil Pediatr 1976; 47: 231-6.

12 Field M. Intestinal secretion. Gastroenterology 1974; 66: 1063-84.

13 Schultz S G, Frizzell A, Nellans H N. Ion transport by mammalian small intestine. Annu Rev Physiol 1974; 36: 51-91.

14 Davidson G P, Gall D G, Petric M, Butler D G, Hamilton J $\mathbf{R}$. Human rotavirus enteritis induced in conventional piglets. J Clin Invest 1977; 60: 1402-9.

15 Levinsky R J, Harvey B A M, Paleja S. A rapid objective method for measuring the yeast opsonisation activity of serum. J Immunol Methods 1978; 24: 251-6.

16 Larcher V F, Mowat A P. Defective opsonisation in liver disease in childhood. Acta Paediatr Belg 1978; 31 : 255.

Correspondence to Dr J T Harries, Department of Child Health, Institute of Child Health, 30 Guilford Street, London WC1N 1EH.

Received 3 April 1979 